\title{
Paestum dietary habits during the Imperial period: archaeological records and stable isotope measurement
}

\author{
Paola Ricci $^{1}$, Carmina Sirignano ${ }^{2}$, Simona Altieri ${ }^{1}$, Mariangela Pistillo ${ }^{3}$, Alfonso Santoriello ${ }^{3}$, Carmine \\ Lubritto ${ }^{1}$ \\ ${ }^{1}$ Department of Environmental, Biological and Pharmaceutical Science and Technology, Second University of Naples, via Vivaldi 43, 81100 \\ Caserta, Italy \\ ${ }^{2}$ Department of Mathematics and Phisics, Second University of Naples, via Vivaldi 43, 81100 Caserta, Italy \\ ${ }^{3}$ Department of Science and Cultural Heritage, University of Salerno, I-84088, Fisciano, Salerno, Italy
}

\section{ABSTRACT}

In historical contexts, analyses of carbon and nitrogen stable isotopes can be useful to answer different question on dietary behavior and to crosscheck information, drawn from texts and classical archaeological investigations. In this study the Isotope Ratio Mass Spectrometry (IRMS) facility installed at the IRMS-SUN Laboratory of the Second University of Naples is presented. Moreover, results coming from application of stable isotope analyses to bone collagen extracted from human remains of the necropolis of "Porta Sirena" in Paestum will be discussed. Finally, a combined analyses of archaeological and historical record and stable isotope measurements permits to expand our knowledge on diet in Roman Paestum.

\section{Section: RESEARCH PAPER}

Keywords: Paleodiet; isotopic analysis; Paestum

Citation: Paola Ricci, Carmina Sirignano, Simona Altieri, Mariangela Pistillo, Alfonso Santoriello, Carmine Lubritto, Paestum dietary habits during the Imperial period: archaeological records and stable isotope measurement, Acta IMEKO, vol. 5, no. 2, article 5, September 2016, identifier: IMEKO-ACTA-05 (2016)-0205

Section Editors: Sabrina Grassini, Politecnico di Torino, Italy; Alfonso Santoriello, Università di Salerno, Italy

Received: March 18, 2016; In final form March 20, 2016; Published September 2016

Copyright: () 2016 IMEKO. This is an open-access article distributed under the terms of the Creative Commons Attribution 3.0 License, which permits unrestricted use, distribution, and reproduction in any medium, provided the original author and source are credited

Funding: This work was supported by Archaeological Superintendence of Salerno, Italy

Corresponding author: Paola Ricci, paola.ricci@unina2.it

\section{INTRODUCTION}

\subsection{Isotopes definitions}

Isotopes are nuclides of a single element that differ in their atomic weights (in particular in neutrons number). Stable isotopes are generally reported as the measured difference in the isotopic composition of the sample (s) and an accepted standard (std), in term of "delta-notation" ( $\delta$-values) (1):

$\delta_{s}(\%)=\frac{R s-R s t d}{R s t d} * 1000$,

where $R$ is the isotope ratio between the heavy isotope and the light one of the same element [1].

Standards used are internationally well defined: for carbon it is the PDB (Peedee Belemnite) and for nitrogen it is Air [1].

Isotopic fractionation is "the partitioning of a sample into two or more parts that have different ratios of heavy and light isotopes than the original ratio"; if one of these parts is "enriched" in the heavy isotope, the other must be "depleted" [1].

\subsection{Paleodiet and stable isotopes}

The paleodiet, the diet of ancient populations, can be investigated with the consolidated methodology using stable isotopes analysis of human bones collagen [2], [3]. De Niro and Epstein conducted first studies on animal feeding, indicating that stable isotopes ratios of carbon and nitrogen of whole body and specific tissues reflect that of the consumed food [4], [5]. Organic and inorganic constituents of bones represent a record of long-term diet [6] and, in specific, bone collagen carries diet information average of several years because of a turnover of ten years [7]. As the isotopic signature varies among different trophic chains (i.e. marine or terrestrial) and it propagates along a chain, it gives reliable indications to 
distinguish whether or not an individual belongs to a certain food chain or to a certain level of it [8]-[11]. It must be considered that between diet and bone collagen there is a fractionation of $+5 \%$ for carbon and $+3 \%$ for nitrogen [12], [13]. About carbon, the $\delta^{13} \mathrm{C}$ signal in human bones reflects the consumption of $\mathrm{C} 3$ and $\mathrm{C} 4$ plants, that have a different metabolic pathway in the photosynthetic cycles [7], [14], [15], with an enrichment of about $14 \%$ for $\mathrm{C} 4$ one. Besides, the majority of marine or terrestrial foods provides changes in $\delta^{13} \mathrm{C}$ of human bones (higher signals for prevalence of marine foods) [7]. Concerning nitrogen isotopes, the majority of the variations in $\delta^{15} \mathrm{~N}$ human collagen derive from trophic level of the food consumed: there is a consistent enrichment in ${ }^{15} \mathrm{~N}$ of marine animals, because phytoplankton uses enriched nitrate dissolved in seawater and because larger marine carnivores, usually common food for humans, are in the higher trophic level [16] For the same reason, small fishes belong to low trophic level and so do not provide great changes in ${ }^{15} \mathrm{~N}$ signal of human bones. Instead, a big consumption of marine foods is detectable in collagen $\delta^{15} \mathrm{~N}$ [17].

Therefore, it is possible to establish ranges of $\delta^{13} \mathrm{C}$ and $\delta^{15} \mathrm{~N}$ human collagen that indicate the main consumption of terrestrial or marine foods: if marine protein were prevalent in the diet of ancient population, $\delta^{13} \mathrm{C}$ results between -12 and -14 $\% 0$ and $\delta^{15} \mathrm{~N}$ is between +12 and $+22 \%$; if they fed more of terrestrial food, $\delta^{13} \mathrm{C}$ values are around $-20 \%$ and $\delta^{15} \mathrm{~N}$ is between +5 and $+12 \%$ [13], [16], [18], [19].

Generally, in a defined historical context, information about foods commonly used in human nutrition is known from archaeological investigations and different models have been implemented in order to untangle the diet of an individual into its different food constituent [20]. But, it appears more difficult to obtain precise information about food consumption as among different social, age and gender groups, within a community or region as a whole. In this case, stable isotopes analysis can be useful to confirm the actual adoption of a certain kind of diet, known to be common at a time.

In particular, historical records or textual references about food and diet during the Roman Imperial period explain that fish or terrestrial animal meat was reserved just to an elite of people [21]. During the last decade, a number of publications have addressed this issue, testing historical accounts by means of stable isotope analysis, in different context in the central and southern Italy. They introduced the hypothesis that together with cereals, wine, olive and dry legumes also animal proteins could have been part of the lower classes diet: pork, sheep and goat meat primarily, but also fish when easy accessible for the population, i.e at costal sites. For an introduction to the food availability and diet during the Roman imperial time see Prowse et al., 2004 [21], Killgrove and Tykot, 2013 [22], and the references therein. Killgrove and Tykot, 2013 [22] and Rutgers et al., 2009 [23] studied the city of Rome itself. The first ones investigated two cemeteries just outside the urban walls, RomeCasal Bertone (2nd-3rd centuries AD) and Rome-Castellaccio Europarco (1st-3rd centuries AD). Rutgers et al., 2009 [23] focused their research on Early Christians buried at the cemetery of St. Callixtus (3rd to 5th centuries AD). However, pioneers in this topic have been Prowse and co-authors [21], [24]-[26], as they extensively investigated the behaviours of the population from Portus Romae (Trajan's port, $23 \mathrm{~km}$ southwest the city of Rome), who was used to bury the corpses in the necropolis of Isola Sacra (1st-3rd centuries). Stable isotope analysis was especially used to look into the diet of the population and how it varied as function of sex, age and status [21], [24] and it revealed that the population generally mixed terrestrial resources with marine food, consuming marine organisms of higher trophic level more than the famous garum, a fish sauce typical of the elite Roman diet. The nearby inland cemetery, named ANAS, was originally intended as reference site for terrestrial based diet. However, final evidences showed that it had been occupied by two different clusters of individuals, identified for their similarity to Isola Sacra individuals, as one group belonging to the inland site, and another one with individuals that possibly migrated from a coastal zone (ANAS 1 and ANAS 2, respectively for our reference) [21]. Craig et al. [27] moved their research southwards and they explored the dietary habits at the coastal sites of Velia. By means of cluster analysis, they revealed that the majority of the population from the Velia necropolis had a diet high in cereals and relatively lower in meat, but they found a group which had consumed more meat and also fish, especially high trophic level fish (Velia 1 and Velia 2, respectively for our reference). About $30 \mathrm{~km}$ to the north of Velia, during the excavations conducted in the area of "Porta Sirena" at Paestum (Salerno, Italy), graves belonging to the Roman Imperial Period came to light. The human remains were studied according to the standards of the funerary archaeology [28] and they have been processed for isotope analysis.

In this study, carbon and nitrogen isotope analyses applied to the human remains of the necropolis of "Porta Sirena" in Paestum are presented. Primarily, this investigation has aimed to verify the hypothesis of presence of fish in the diet at this shore site during the Roman Imperial time, especially by comparing coeval sites. Furthermore, since more studies on this topic have been invoked as desirable (see for example Killgrove et al. 2013 [22]), this work is expected to generally contribute to the knowledge on average lower class diet from this time, which is complex and variable in its distribution among different kind of people and different territories.

Anthropological assessments are not covered by this study and samples were collected only for paleodiet analysis. But for the purpose of the study itself, it is important to consider that the grave goods found in the site were in no case valuable or interesting, confirming the absence of any elite member of the community interred in this necropolis.

\section{MATERIALS AND METHODS}

\subsection{Site description}

The area of the excavation is located along North-South direction of "Porta Sirena" (Figure 1), while the eastern and western limits of the zone of operation are respectively represented by the modern road and the walls. The area has been divided into different sectors. The excavation of the necropolis, whose tombs are located at about 10-15 cm depth, have so far returned 73 burials, numbered from 21 to 95 (t21 to t95). According to their stratigraphy and the archaeological analysis of the grave goods, the interments have been attributed to a period spanning from the 2 nd to the 4th centuries AD.

\subsection{Paleodiet analysis}

For the scope of this study, 23 of the 73 discovered graves have been sampled for paleodiet analysis. The choice fell on those graves where the human remains were better preserved, preferring those among them who by inhumation and grave 


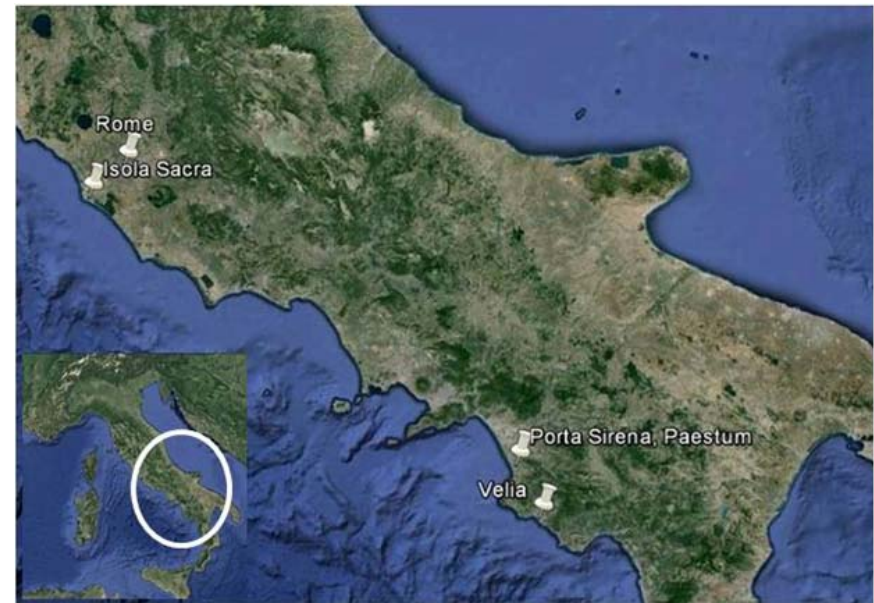

Figure 1. Map of South of Italy with the location of the necropolis of "Porta Sirena at Paestum and the coeval sites considered in the text. The necropolis of Velia is located to the south of Paestum, while to the North, near Rome there is the cemetery of Isola Sacra (Casa Bertone, Castellaccio Europarco and St Callisto are too close to Rome be distinguished at this scale).

goods were more heterogeneous, in order to be as more representative as possible of the whole interred population of the cemetery. The graves in amphorae, were excluded from this study, as they were usually used for very young corpses. Long bones, when available, have been preferred to the others, in order to obtain information about lifelong habits of the sampled individuals, and, when possible, the same skeletal element has been chosen for all the individuals, in order to minimize the influence arising from sampling different kind of bones. The classification of sampled bones is reported in Table 1 , in addition to the age classification, $\mathrm{C}$ and $\mathrm{N}$ concentrations,
$\mathrm{C} / \mathrm{N}$ ratios, $\mathrm{C}$ and $\mathrm{N}$ isotopic ratios, collagen yield and presence of grave goods. Faunal remains were rare and not properly preserved for classification, for reference purposes two teeth of two different herbivores (possibly a cow indicated as $\mathrm{d} 1$ and a goat as d2) have been collected at the site, being coeval with the human individuals under investigation.

\subsection{Samples preparation}

The samples for the analysis were processed to isolate the organic phase of the sample (collagen) adopting a modified procedure from Longin method (1971) [29]. A fragment of the sample was selected from each specimen. The bone surface was abraded to remove contaminants and it was pulverized. Each sample was then placed in polypropylene test tubes and demineralised in a sequence of acid attacks with hydrochloric acid $(\mathrm{HCl}) \quad 0.6 \mathrm{M}$ at ambient temperature $\left(20-25{ }^{\circ} \mathrm{C}\right)$, interrupted by one alkali attack $(\mathrm{NaOH} 0.1 \mathrm{M}) 30$ minutes long. Several rinses with de-ionized water were done after each step, before finally oven-drying the samples. Finally, the gelatinization protocol was applied [29], [30].

\subsection{Elemental analysis (EA) and Stable Isotopes Mass Spectrometry (IRMS)}

The Isotope Ratio Mass Spectrometry (IRMS) is a methodology used for qualitative and quantitative analyses, measuring isotopic ratios of different element of various types of samples (solid, liquid or gas). It is based on the principle of separation of atoms or rather ions with different mass to measure their relative abundances [31].

For solid samples, it is coupled with an Elemental Analyzer (EA), where the sample is burned and transported by a carrier flow (He) to the IRMS, as showed in the schema of the instrumentation used at IRMS-SUN Laboratory (Figure 2).

For collagen quality test, $\mathrm{C}$ and $\mathrm{N}$ fractions of collagen dry

Table 1. Samples classifications, isotopic values and collagen quality indicator of human's bone and fauna's teeth samples from the necropolis "Porta Sirena" of Paestum.

\begin{tabular}{|c|c|c|c|c|c|c|c|c|c|}
\hline Sample & $\begin{array}{c}\text { Sample } \\
\text { classification }\end{array}$ & $\begin{array}{c}\text { Age } \\
\text { classification }\end{array}$ & $\% \mathrm{~N}$ & $\% \mathrm{C}$ & $\mathrm{C} / \mathrm{N}$ & $\begin{array}{c}\delta^{13} \mathrm{C} \\
(\% \circ \mathrm{VPDB})\end{array}$ & $\begin{array}{c}\delta^{15} N \\
(\% \text { AIR) }\end{array}$ & $\begin{array}{c}\text { Collagen } \\
\text { yield }\end{array}$ & $\begin{array}{l}\text { Presence of } \\
\text { grave goods }\end{array}$ \\
\hline Herbivorous d1 & Tooth & - & 3.9 & 10.8 & 3.3 & -21.9 & 4.7 & $3.1 \%$ & \\
\hline Herbivorous d2 & Tooth & - & 7.1 & 19.9 & 3.3 & -22.1 & 5.1 & $1.9 \%$ & \\
\hline t24 & Radius sx & Adult & 14.1 & 37.1 & 3.1 & -19.0 & 7.8 & $2.4 \%$ & \\
\hline $\mathrm{t} 26$ & Radius sx & Adult & 16.1 & 41.1 & 3.0 & -19.5 & 7.6 & $3.6 \%$ & \\
\hline $\mathrm{t} 34$ & Tibia dx & Adult & 12.8 & 33.2 & 3.0 & -19.3 & 8.5 & $2.7 \%$ & $x$ \\
\hline $\mathrm{t} 38$ & Tibia $\mathrm{dx}$ & Adult & 12.8 & 33.8 & 3.1 & -20.9 & 7.6 & $2.9 \%$ & $x$ \\
\hline $\mathrm{t} 46$ & Femur dx & Sub-adult & 13.7 & 38.6 & 3.3 & -20.5 & 7.1 & $1.6 \%$ & $x$ \\
\hline $\mathrm{t} 47$ & Humerus sx & Adult & 14.9 & 38.3 & 3.0 & -19.4 & 7.9 & $1.5 \%$ & $x$ \\
\hline $\mathrm{t} 53$ & Femur $\mathrm{dx}$ & Sub-adult & 15.8 & 41.5 & 3.1 & -19.1 & 7.8 & $2.6 \%$ & $x$ \\
\hline $\mathrm{t} 58$ & Ulna & Adult & 15.7 & 40.7 & 3.0 & -19.0 & 7.9 & $2.5 \%$ & \\
\hline t64 & Ulna & Adult & 16.7 & 42.9 & 3.0 & -18.5 & 8.2 & $4.7 \%$ & \\
\hline t65 & Femur $\mathrm{dx}$ & Sub-adult & 15.5 & 41.2 & 3.1 & -20.4 & 7.4 & $3.9 \%$ & $x$ \\
\hline t68 & Humerus dx & Adult & 8.9 & 22.9 & 3.0 & -18.5 & 9.4 & $3.9 \%$ & $x$ \\
\hline $\mathrm{t} 70$ & Tibia sx & Adult & 16.0 & 40.9 & 3.0 & -18.8 & 8.1 & $3.1 \%$ & $x$ \\
\hline $\mathrm{t} 72$ & Tibia sx & Sub-adult & 14.4 & 37.5 & 3.0 & -19.4 & 7.9 & $1.2 \%$ & $x$ \\
\hline $\mathrm{t} 76$ & Femur sx & Adult & 14.9 & 38.3 & 3.0 & -20.1 & 7.6 & $2.4 \%$ & \\
\hline t77 & Tibia $\mathrm{dx}$ & Adult & 14.2 & 36.5 & 3.0 & -20.0 & 7.8 & $3.1 \%$ & $x$ \\
\hline t80 & Humerus dx & Adult & 14.9 & 38.2 & 3.0 & -19.0 & 7.5 & $1.0 \%$ & $x$ \\
\hline t81 & Tibia sx & Adult & 14.0 & 37.1 & 3.1 & -19.6 & 8.0 & $1.8 \%$ & \\
\hline t82 & Humerus sx & Adult & 13.8 & 36.9 & 3.1 & -20.3 & 8.2 & $1.0 \%$ & $x$ \\
\hline t83 & Tibia sx & Infant & 11.3 & 29.8 & 3.1 & -18.4 & 11.4 & $2.6 \%$ & $x$ \\
\hline t84 & Humerus dx & Adult & 15.8 & 40.6 & 3.0 & -19.9 & 8.8 & $3.2 \%$ & $x$ \\
\hline t85 & Tibia dx & Adult & 15.4 & 40.0 & 3.0 & -20.6 & 8.4 & $2.7 \%$ & $x$ \\
\hline t86 & Humerus dx & Adult & 16.3 & 41.6 & 3.0 & -19.3 & 8.4 & $3.2 \%$ & $x$ \\
\hline
\end{tabular}




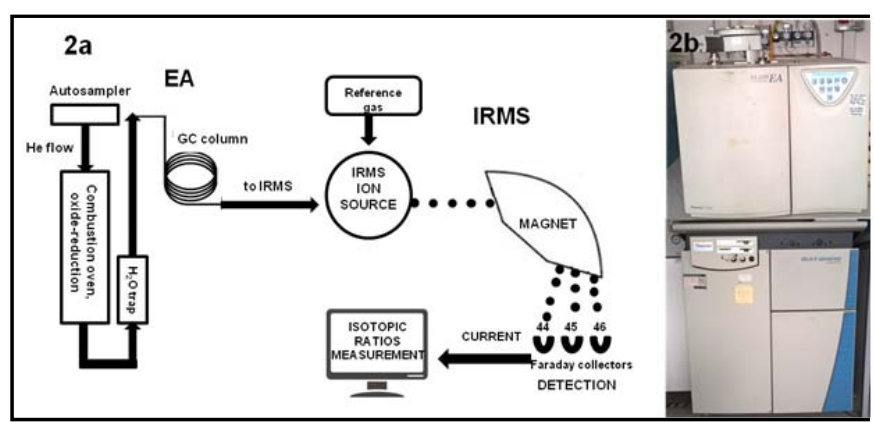

Figure 2. EA/IRMS facility (2a) and pictures of EA and IRMS instruments (2b) of the IRMS-SUN Laboratory.

mass (C \% and $\mathrm{N} \%$ ) were measured with the Elemental Analyzer alone (CN Flash EA 1112 Series, Thermo Scientific, Finningan). In specific, each sample is weighed in a tin capsule (about $3 \mathrm{mg}$ ), placed in an auto-sampler and burned in the reaction column of the EA, by high temperature $\left(1020^{\circ} \mathrm{C}\right)$ and oxygen presence. Here, the sample derived gas is subjected to red-ox reactions, obtaining $\mathrm{CO}_{2}$ and $\mathrm{N}_{2}$ gases, subsequently separated in a chromatographic column, carried by the helium. Finally, the gases are captured by a detector: software allows the concentrations calculation, by means of a calibration curve obtained using a standard with certified concentrations. During the gases passage, water is removed by a hygroscopic trap (magnesium perchlorate).

The Elemental Analyzer, in our system, is connected to the IRMS (Delta V Advantage, Thermo Scientific) for isotopic ratios analysis (1 $\mathrm{mg}$ of samples), by an interface CONFLO III (in CONtinuous FLOw mode, Thermo Finningan), that modulates the passage of carrier flow and standard gases. In the IRMS, the gas sample is ionized by particles coming from a source, the resulting ions are accelerated in an electronic field to a magnetic field, where they have different trajectory depending on their mass/charge ratio.

Trajectories of lighter and heavier isotopes are deflected in different ways, following the relation (2):

$\frac{m}{q}=\frac{r^{2}}{2 V} B^{2}$,

where $m$ is the mass, $q$ the charge, $r$ is the radius of curvature of ions beam trajectory, $V$ the potential differences and $B$ the magnetic field.

Ions beams are collected by Faraday cups (collectors), which are able to measure current intensity generated by incident beam. A mass spectrum is derived, where each line corresponds to a fragment of specific $m / q$. Molecular peak (more intense) is made from molecular ion, that is a non fragmented molecule with a positive charge (for a lost electron). Peak position is related to a specific mass value (qualitative analyses), peak intensity is proportional to relative abundance of each fragment (quantitative analyses).

Samples were retained for isotope analyses when extracted collagen achieved a yield higher than $1 \%$ and an atomic C:N ratio between 2.9 and 3.6 [30]-[34]. For $\delta^{15} \mathrm{~N}$ and $\delta^{13} \mathrm{C}$ analyses, samples were analysed according to the method used by Preston and Ovens 1985 [35].

The isotopic measurements were calibrated based on the measurement of standards, aiming to set their values on internationally referenced scales (VPDB for C and Air for N) [36]. The analyses were conducted in blocks of 12 samples, maximum. Between one block and the next one, three different reference materials were measured: two used to calibrate the measurement, and the last one used to evaluate the proper conduct of the analysis (target) and the repeatability of the measurement itself. The reference materials used for $\delta^{15} \mathrm{~N}$ analysis calibration were IAEA-N-2 (ammonium sulphate, $\delta^{15} \mathrm{~N}_{\text {Air }}=20.3 \pm 0.2 \%$ ) and IAEA-N-1 (ammonium sulphate, $\delta^{15} \mathrm{~N}_{\text {Air }}=0.4 \pm 0.2 \%$ ) [37]. The reference materials used for $\delta^{13} \mathrm{C}$ analysis were IAEA-CH6 (sucrose, $\delta^{13} \mathrm{C}_{\mathrm{VPDB}}=-10.45 \pm$ $0.03 \%$ ) and IAEA-CH3 (cellulose, $\delta^{13} \mathrm{C}_{\mathrm{VPDB}}=-24.72 \pm 0.04$ $\% 0$ ) [38]. Typical analytical precision evaluated from repeated measurements of the standard, used as target, is $0.1 \%$ for $\delta^{13} \mathrm{C}$ and $0.2 \%$ for $\delta^{15} \mathrm{~N}$.

\section{RESULTS AND DISCUSSION}

The results of the isotopic analysis are shown in Table 1 $\left(\delta^{13} \mathrm{C}\right.$ and $\left.\delta^{15} \mathrm{~N}\right)$, together with collagen quality indicators $(\mathrm{C} / \mathrm{N}$, collagen yield). The general state of preservation of the sampled bones has been acceptable. Testing the quality of collagen extracted assures the absence of potential contamination effects. From the results obtained, all the samples were retained for analysis, presenting yields above $1 \%$ and $\mathrm{C} / \mathrm{N}$ values spanning from 3.0 to 3.3 [31]-[34].

Figure 3 represents the $\delta^{13} \mathrm{C}$ and $\delta^{15} \mathrm{~N}$ bi-variate plot which finally allows considerations on the dietary habits. All the results from the necropolis of "Porta Sirena" in Paestum are plotted as compared to the faunal remains, the ones found at the same site (triangles) and the fauna collected at the coeval sites of Velia (diamonds) [27] and Isola Sacra (circles) [21], in particular pigs and herbivores. The isotopic composition of the two fauna samples from Paestum falls well within the variability shown by the coeval fauna from the other sites, both Isola Sacra and Velia.

Regarding to the humans, the collagen extracted from the bone sampled in the tomb t83 has given delta values clearly very different from those found for other samples. The bone fragments extracted from tomb t83 have been attributed to an individual younger than 1 year, an infant, i.e. a breast-feeding baby. Breastfeeding individuals can be considered "consumers" of their mother's tissues, therefore occupying a higher trophic level than the adults and the weaned children. A ${ }^{15} \mathrm{~N}$

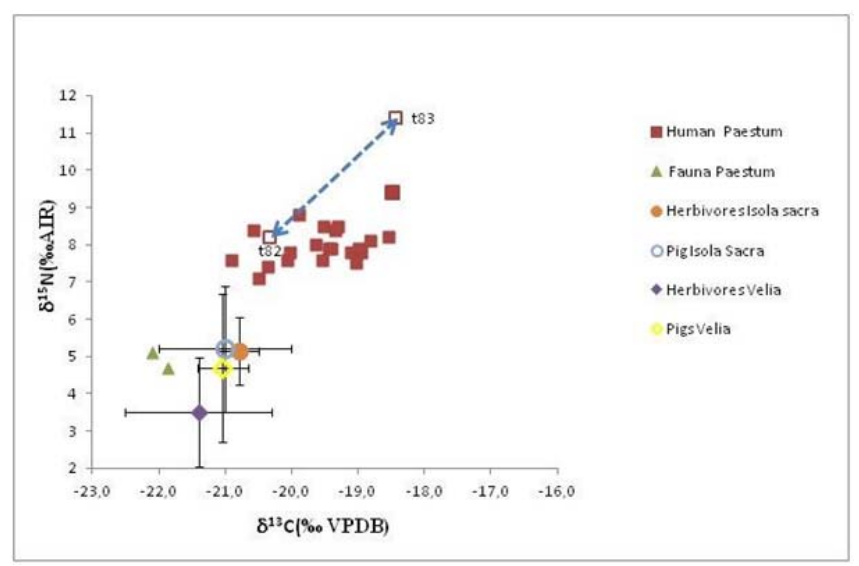

Figure 3. $\delta^{13} \mathrm{C}$ and $\delta^{15} \mathrm{~N}$ values for humans (squares) and herbivorous fauna (triangles) from Paestum compared with fauna from coeval costal sites of Isola Sacra (circles) and Velia (diamonds), average values with standard deviation. The individuals $\mathrm{t} 82$ and $\mathrm{t} 83$ are possibly mother and her breast feeding baby. 
enrichment of about +2 and $+3 \%$ and a ${ }^{13} \mathrm{C}$ enrichment of about $1 \%$ are typical for this trophic shift [39], [40]. This $\delta^{13} \mathrm{C}$ and $\delta^{15} \mathrm{~N}$ offset pattern is consistent with what we find for this individual t83. Being t83 a child early in life, it is very likely that the individual laying in the same grave (t82) might have been his/her mother. They differ from each other of $1.9 \%$ on the $\delta^{13} \mathrm{C}$ scale and of $3.2 \%$ on the $\delta^{15} \mathrm{~N}$ scale, which is a result that could indicate the trophic shift mother-baby. But this could only be confirmed in response to anthropological analysis (i.e. individuals sex).

If we exclude the sample belonging to the tomb t83 all the $\delta^{13} \mathrm{C}$ and $\delta^{15} \mathrm{~N}$ values are included respectively in the ranges [$20.9 \%,-18.5 \% 0]$ and $[+7.1 \% 0,+9.4 \% 0]$. According to these results one can say that the diet of the Paestum population buried at the necropolis of "Porta Sirena" was based on agricultural-pastoral foods, confirming the indications known from independent archaeological studies [28]. The values obtained, in fact, are consistent with a diet based on the consumption of $\mathrm{C} 3$ plants, characteristics of temperate climates, with addition of meat as confirmed by the fact that the average of human population (excluding t83) is about $2.4 \%$ and of 3.1 $\%$ higher than herbivores samples on the $\delta^{13} \mathrm{C}$ and the $\delta^{15} \mathrm{~N}$ scale, respectively. However, this analysis has the limitation of not being able to identify the possible consumption of small fish [17], as explained following in this paragraph.

Figure 4 and Table 2 compare the results from Paestum with those from the coeval sites from the central and south of Italy shown for their location on the map of Figure 1. Velia is the closest site and it has been the largest investigated site together with Isola Sacra, in term of analyzed individuals. In their extensive investigations Craig et al. (2009) [27] for Velia (diamonds) and Prowse et al. (2004) [21] for Isola Sacra (triangles) have been able to distinguish among groups of the population, which had different consume of meat and, especially, of fish in their diet. Here we refer to these categories to further interpret the results of the smaller population sampled at Paestum. The groups which very likely introduced fish in their diets have been here defined for simplicity "fish eaters" (Isola Sacra, ANAS 2 and Velia 2), the others have been named "non fish eaters" (Velia 1, ANAS 1). Fish eaters at Velia belongs to a small group of 17 individuals (Velia 2, empty symbols), while all individuals from Isola Sacra are thought to introduce to some extent marine food in their diets. In the original study, Isola Sacra samples were compared with individuals buried in a nearby inland place named ANAS (triangle). In the ANAS cemetery just a subset of inhumed individuals was identified with a terrestrial diet (ANAS 1, full symbols), the rest was formed by costal immigrant or seafarers

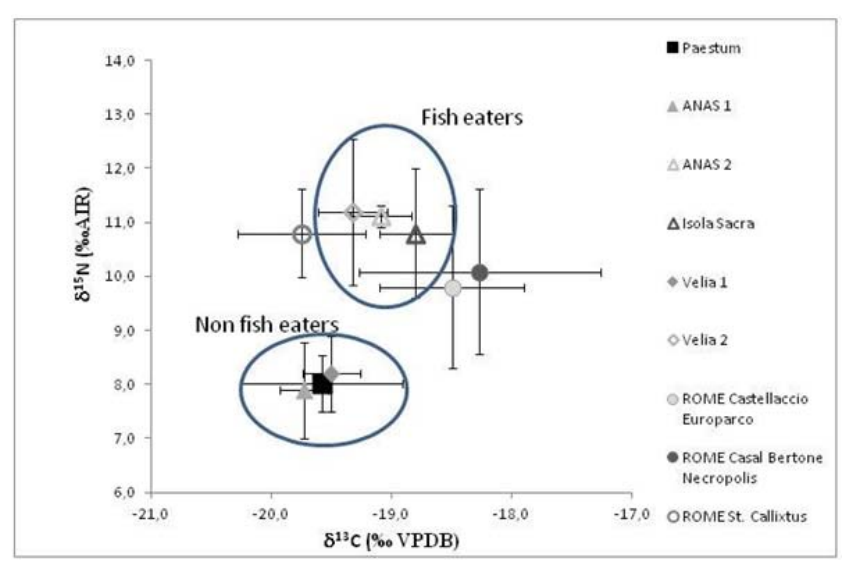

Figure 4. $\delta^{13} \mathrm{C}$ and $\delta^{15} \mathrm{~N}$ bi-variate plot with the comparison between Paestum and other coeval sites (average values with standard deviation) . Isola Sacra (empty dark triangle), ANAS 2 (empty light gray triangle) and Velia 2 (empty diamond) have been grouped to identify them as "fish eaters". Velia1 (full diamond) and ANAS1 (full triangle) are indicated as "non fish eaters". Circles represent the mean values from the cemeteries belonging to the city of Rome (Rome-Casal Bertone, Rome-Castellaccio Europarco and the Early Christian cemetery of St. Callixtus). Error bars are standard deviations.

(ANAS 2, full symbols). The $\delta{ }^{13} \mathrm{C}$ and $\delta^{15} \mathrm{~N}$ of human individuals found at the necropolis of "Porta Sirena" in Paestum averaged (excluding t83) - $19.6 \%$ \% $(s=0.7 \%, \mathrm{n}=22)$ and $+8.0 \%$ o $(s=0.5 \% 0, \mathrm{n}=22)$, respectively. On the one hand, the mean $\delta^{13} \mathrm{C}$ of the fish eaters group is $-18.9 \%$ ( $\mathrm{s}=0.4 \%$, $\mathrm{n}=126)$ and the mean $\delta^{15} \mathrm{~N}$ is $+10.9 \%$ ( $\left.=1.2 \% 0, \mathrm{n}=125\right)$. These values are significantly higher than the values found at Paestum (two-sample t-test, $\mathrm{p}<0.001 ; \mathrm{t}=4.7$ for the difference in $\delta^{13} \mathrm{C}, \mathrm{t}=18.9$ for the difference in $\left.\delta^{15} \mathrm{~N}\right)$. On the other hand, the human individuals found at the necropolis of "Porta Sirena" in Paestum show unequivocal analogy with the group identified as non fish eaters, mainly coming from Velia, whose mean $\delta^{13} \mathrm{C}$ is $-19.5 \%$ ( $\mathrm{s}=0.2 \%, \mathrm{n}=106)$ and $\delta{ }^{15} \mathrm{~N}$ is $+8.2 \%$ ( $\mathrm{s}=0.7 \%$, $\mathrm{n}=106$ ), suggesting that these individuals had a negligible or no use of sea food in their diets (two-sample t-test, $\mathrm{p}<0.001$; $\mathrm{t}=0.6$ for the difference in $\delta^{13} \mathrm{C}, \mathrm{t}=1.3$ for the difference in $\left.\delta^{15} \mathrm{~N}\right)$.

However, as mentioned before, it remains the hypothesis that "Porto Sirena" population could eat fish in a minor amount respect to other food, because marine protein could represent up to $20 \%$ of total dietary protein without any appreciable change in ${ }^{13} \mathrm{C}$ values and consuming low trophic level marine resources (e.g. garum) could not change significantly ${ }^{15} \mathrm{~N}$ signal [21].

Table 2. Isotopic average values and standard deviations (s) of isotopic results from different sites (see references), where $\mathrm{n}$ is the number of samples.

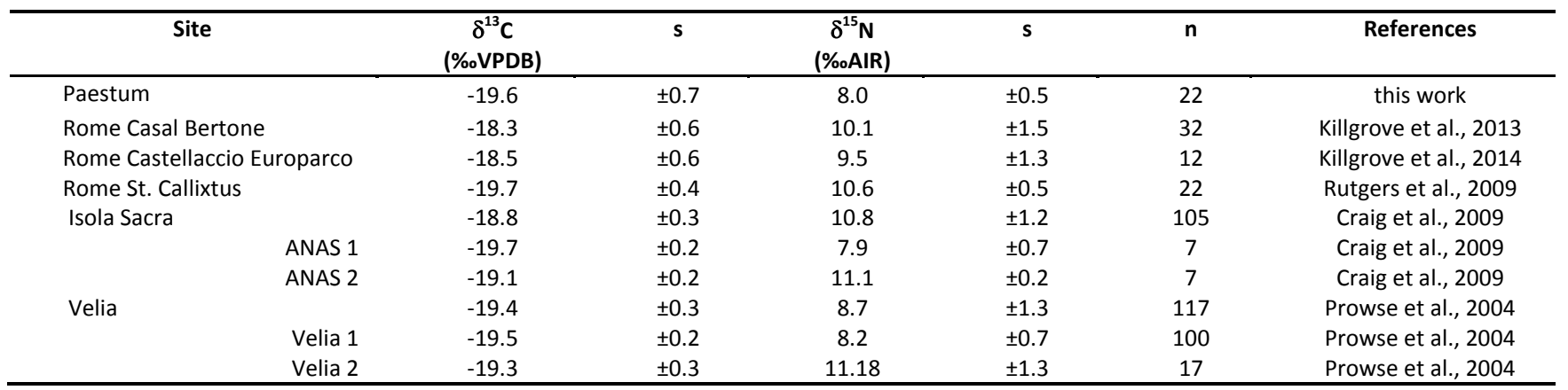


A third subset of three sites belongs to the city of Rome: two cemeteries just outside the urban walls, Rome-Casal Bertone (2nd-3rd centuries AD) and Rome-Castellaccio Europarco (1st-3rd centuries AD) and the Early Christian cemetery of St. Callixtus ( 3 rd to 5 th centuries AD). Results of the dietary analysis from periurban Casal Bertone and suburban Castellaccio Europarco showed evidences that individuals living closer to the city of Rome were consuming some aquatic resources, those in the suburbium made greater use of millet [22], as could possibly have done some of the individuals buried at Paestum showing higher $\delta^{13} \mathrm{C}$ values. The access to aquatic resources of Tiber, instead, were used by Rutgers and colleagues (2009) to interpret the comparatively low $\delta^{13} \mathrm{C}$ values as related to freshwater fish consumption. Beyond this, there is to be noted that the intra-site and inter-site variability existed in the diet of the common people during the Roman Imperial period, Paestum population, however, does not show signs of this complexity, appearing as a simple rural community, in accordance with the classical paradigm that fish or terrestrial animal meat was reserved to elite people, even when sea resources were so close in space. However, we could not bring any evidences of variability of the dietary behavior according to any hierarchical or social status in Paestum. In addition, no particular status distinction among the inhumed individuals was found at the site, as testified, for example, by the kind of tombs and the simple grave goods found in that.

\section{CONCLUSIONS}

This work has confirmed that isotopic measurements can integrate classical archaeological investigations to improve the knowledge of diet in Imperial Roman Paestum. As matter of fact, archaeological study allows to place the site chronologically, identifying analogies with the contemporary and vicinal necropolis of Velia, especially with respect to homogeneity in the poverty of the materials and rituals of burial. The isotopic analysis outlines uniformity even in the diet, identifying a typical agricultural-pastoral diet. We can therefore assume a homogeneous social structure, based on a predominantly rural economy, where, despite its proximity, the sea seems not be regarded as a source of food, maybe because it was still not easily accessible. While showing analogies with the coeval and close by site of Velia, isotope analysis revealed also many differences with the city of Rome and its nearby coast.

\section{ACKNOWLEDGEMENT}

The excavation of the necropolis is part of a project originally aiming to cataloguing and restoring the stone elements placed along the east side of the city walls of Paestum. This European-funded project, sponsored by the Archaeological Superintendence of Salerno, was done in collaboration with the University of Salerno, in particular with the archaeological laboratory of Mario Napoli, belonging to the department of Cultural Heritage.

\section{REFERENCES}

[1] R.E. Criss, "Principles of stable isotope distibution", Oxford University Press, 1999, pp.254.

[2] N.J. van der Merwe, J.C. Vogel, "13C Content of human collagen as a measure of prehistoric diet in woodland North America", Nature, vol.276, 1978, pp.815-816.
[3] J.C. Vogel, N.J. van der Merwe, "Isotopic Evidence for Early Maize Cultivation in New York State", Am. Antiquity, vol.42, 1977, pp.238-242.

[4] M.J. DeNiro, S. Epstein, "Influence of diet on the distribution of carbon isotopes in animals", Geochim. Cosmochim. Ac., vol.42, 1978, pp. 495-506.

[5] M.J. DeNiro, S. Epstein, "Influence of diet on the distribution of nitrogen isotopes in animals", Geochim. Cosmochim. Ac., vol.45, 1981, pp.341-351.

[6] F. D. Pate, "Bone Chemistry and Paleodiet: Reconstructing Prehistoric Subsistence-Settlement Systems in Australia", Journal of Anthropological Archaeology, vol.16, 1997, pp.103-107

[7] H.P. Schwarcz, M.J. Schoeninger, "Stable isotope analyses in human nutritional ecology", Am. J. Phys. Anthropol., vol.86, 1991, pp. 283-321.

[8] M.J. Schoeninger, K. Moore, "Bone stable isotope studies in archaeology”, J. World Prehist., vol.6, 1992, pp.247-296.

[9] M.A. Katzenberg, R.G. Harrison, "What's in a bone? Recent advances in archaeological bone chemistry", J. Archaeol. Res., vol.5, 1997, pp.265-293.

[10] S.H. Ambrose, J. Krigbaum, "Bone chemistry and bioarchaeology”, J. Anthropol. Archaeol., vol.22, 2003, pp.193199.

[11] B. Fry, "Stable isotope ecology", Springer New York, 2006.

[12] R.H. Tykot, F. Falabella, M.T. Planella, E. Aspillaga, L. Sanhueza, C. Becker, "Stable isotopes and archaeology in Central Chile: methodological insights and interpretative problems for dietary reconstruction", International Journal of Osteoarchaeology, vol.19, 2009, pp.156-170.

[13] M. Torino, J.L. Boldsen, P. Tarp, K.L. Rasmussen, L. Skytte, L. Nielsen, S. Schiavone, F. Terrasi, I. Passariello, P. Ricci, C. Lubritto, "Convento di San Francesco a Folloni: the function of a Medieval Franciscan Friary seen through the burials", Heritage Science, vol.3 (27), 2015, pp. 1-27.

[14] G.D. Farquhar, J.R. Ehleringer, K.T. Hubick, "Carbon Isotope Discrimination and Photosynthesis", Annu. Rev. Plant Phys., vol.40, No.1, 1989, pp.503.

[15] M.H. O'Leary, "Carbon isotope fractionation in plants", Phytochemistry, vol.20, 1981, pp.553-567.

[16] M.J. Schoeninger, M.J. DeNiro, "Nitrogen and carbon isotopic composition of bone collagen from marine and terrestrial animals", Geochim. Cosmochim. Ac, vol.48, 1984, pp.625-639.

[17] H.P. Schwarcz, C.D. White, F.J. Longstaffe, "Stable and Radiogenic Isotopes in Biological Archaeology: Some Applications", in Isoscapes Understanding movement, pattern, and process on Earth through isotope mapping G.J.B.T.E.D. Jason B. West, P.T. Kevin (Eds.), Springer Science, 2010.

[18] B.S. Chisholm, D.E. Nelson, H.P. Schwarcz, "Stable-Carbon Isotope Ratios as a Measure of Marine versus Terrestrial Protein in Ancient Diets", Science, vol.216,1982, pp.1131-1132.

[19] M.J. Schoeninger and M.J. De Niro, "Stable Nitrogen Isotope Ratios of Bone Collagen Reflect Marine and Terrestrial Components of Prehistoric Human Diet", Science, vol.220, $\mathrm{n}^{\circ} 4604,1983$, pp.1381-1383

[20] H.P. Schwarcz, "Some theoretical aspects of isotope palediet studies", J. Archaeol. Sci., vol.18, 1991, pp.261-275.

[21] T. Prowse, H.P. Schwarcz, S. Saunders, R. Macchiarelli, L. Bondioli, "Isotopic paleodiet studies of skeletons from the imperial Roman-age cemetery of Isola Sacra, Rome, Italy", J. Archaeol. Sci., vol.31, 2004, pp.259-272.

[22] K. Killgrove, R.H. Tykot, "Food for Rome: A stable isotope investigation of diet in the Imperial period (1st-3rd centuries AD)", J. Anthropol. Archaeol., vol.32, 2013, pp.28-38.

[23] L.V. Rutgers, M.v. Strydonck, M. Boudin, C.v.d. Linde, "Stable isotope data from the early Christian catacombs of ancient Rome: new insights into the dietary habits of Rome's early Christians", J. Archaeol. Sci., vol.36, 2009, pp.1127-1134.

[24] T.L. Prowse, H.P. Schwarcz, S.R. Saunders, R. Macchiarelli, L. Bondioli, "Isotopic evidence for age-related variation in diet 
from Isola Sacra, Italy", Am. J. Phys. Anthropol., vol.128, 2005, pp.2-13.

[25] T.L. Prowse, S.R. Saunders, H.P. Schwarcz, P. Garnsey, R. Macchiarelli, L. Bondioli, "Isotopic and dental evidence for infant and young child feeding practices in an imperial Roman skeletal sample”, Am. J. Phys. Anthropol., vol.137, 2008, pp.294308.

[26] T. Prowse, H. Schwarcz, P. Garnsey, M. Knyf, R. Macchiarelli, L. Bondioli, "Isotopic evidence for age-related immigration to imperial Rome", Am. J. Phys. Anthropol., vol.132, 2007, pp.510519.

[27] O.E. Craig, M. Biazzo, T.C. O'Connell, P. Garnsey, C. MartinezLabarga, R. Lelli, L. Salvadei, G. Tartaglia, A. Nava, L. Reno, A. Fiammenghi, O. Rickards, L. Bondioli, "Stable Isotopic Evidence for Diet at the Imperial Roman Coastal Site of Velia (1st and 2nd Centuries AD) in Southern Italy", Am. J. Phys. Anthropol., vol.139, 2009, pp.572-583.

[28] M. Pistillo, "Analisi di paleodieta della necropoli di Porta Sirena, Paestum. in: MSc Thesis University of Salerno", 2008.

[29] R. Longin, "New method of collagen extraction for radiocarbon dating", Nature, vol.230, 1971, pp.241-242.

[30] M.J. DeNiro, "Postmortem preservation and alteration of in vivo bone collagen isotope ratios in relation to palaeodietary reconstruction", Nature, vol.317, 1985, pp.806-809.

[31] W.G. Mook, "Introduction to isotope hydrology: stable and radioactive isotopes of hydrogen, oxygen and carbon. Taylor \& Francis Group, London, Great Britain, 2005, pp. 226.

[32] R.C. Dobberstein, M.J. Collins, O.E. Craig, G. Taylor, K.E.H. Penkman, S. Ritz-Timme, "Archaeological collagen: Why worry about collagen diagenesis?", Archaeol. Anthropol. Sci., vol.1, 2009, pp.31-42.

[33] G.J. van Klinken, "Bone Collagen Quality Indicators for Palaeodietary and Radiocarbon Measurements", J. Archaeol. Sci., vol.26, 1999, pp.687-695.

[34] F.D. Pate, "Bone Chemistry and Paleodiet", J. Archaeol. Method Th., vol.1, 1994, pp.161-209.

[35] T. Preston, N.J.P. Owens, "Preliminary 13C measurements using a gas chromatograph interfaced to an isotope ratio mass spectrometer", Biol. Mass Spectrom., vol.12, 1985, pp.510-513.

[36] T.B. Coplen, "Guidelines and recommended terms for expression of stable-isotope-ratio and gas-ratio measurement results”, Rapid Commun. Mass Sp., vol.25, 2011, pp.2538-2560.

[37] J.K. Böhlke, C.J. Gwinn, T.B. Coplen, "New reference materials for nitrogen isotope ratio measurements", Geostandards Newsletter, vol.17, 1993, pp.159-164.

[38] T.B. Coplen, W.A. Brand, M. Gehre, M. Groning, H.A.J. Meijer, B. Toman, R.M. Verkouteren, "New Guidelines for 13C Measurements", Anal. Chem., vol.78, 2006, pp.2439-2441.

[39] E. Nitsch, L. Humphrey, R. Hedges, "Using stable isotope analysis to examine the effect of economic change on breastfeeding practices in Spitalfields, London, UK”, Am. J. Phys. Anthropol., vol.146, 2011, pp.619-628.

[40] B.T. Fuller, J.L. Fuller, D.A. Harris, R.E.M. Hedges, "Detection of breastfeeding and weaning in modern human infants with carbon and nitrogen stable isotope ratios", Am. J. Phys. Anthropol., vol.129, 2006, pp.279-293. 